\title{
Safety and cardiovascular effects of multiple-dose administration of aripiprazole and olanzapine in a randomised clinical trial
}

Dora Koller, MSc ${ }^{1}$, Susana Almenara, MD ${ }^{1}$, Gina Mejía, $\mathrm{MD}^{1,2}$, Miriam Saiz-Rodríguez, $\mathrm{PhD}^{1,3}$, Pablo Zubiaur, MPharm ${ }^{1}$, Manuel Román, $\mathrm{MLT}^{1,2}$, Dolores Ochoa, $\mathrm{MD}, \mathrm{PhD}^{1,2}$, Aneta Wojnicz, $\mathrm{PhD}^{1}$, Samuel Martín, $\mathrm{PhD}^{1,2}$, Daniel RomeroPalacián, $\mathrm{MD}^{1}$, Marcos Navares-Gómez, $\mathrm{MLT}^{1}$, Francisco Abad-Santos, MD, $\mathrm{PhD}^{1,2}$

${ }^{1}$ Clinical Pharmacology Department, Hospital Universitario de La Princesa, Instituto Teófilo Hernando, School of Medicine, Universidad Autónoma de Madrid, Instituto de Investigación Sanitaria La Princesa (IP), Madrid, Spain

${ }^{2}$ UICEC Hospital Universitario de La Princesa, Platform SCReN (Spanish Clinical Research Network), Instituto de Investigación Sanitaria La Princesa (IP), Madrid, Spain

${ }^{3}$ Research Unit, Fundación Burgos por la Investigación de la Salud, Hospital Universitario de Burgos, Burgos, Spain.

\section{Corresponding author}

Dr. Francisco Abad-Santos

Clinical Pharmacology Department,

Hospital Universitario de La Princesa

Diego de León 62., 28006 Madrid, Spain

Tel: 34 915202425; Fax: 34915202540

E-mail: francisco.abad@salud.madrid.org

\section{Short title}

Aripiprazole and olanzapine influence on safety

\section{Source of Funding}

D. Koller is co-financed by the H2020 Marie Sklodowska-Curie Innovative Training Network 721236 grant. M. Navares is co-financed by the "Consejería de Educación, Juventud y Deporte" PEJ-2018-TL/BMD-11080 grant from "Comunidad de Madrid" and "Fondo Social Europeo". 
medRxiv preprint doi: https://doi.org/10.1101/2020.08.03.20167502; this version posted August 7, 2020. The copyright holder for this preprint (which was not certified by peer review) is the author/funder, who has granted medRxiv a license to display the preprint in All rights reserved. No reuse allowed without permission.

\section{Abstract}

Objective: To assess adverse events and safety of aripiprazole and olanzapine treatment.

Methods: Twenty-four healthy volunteers receiving 5 daily oral doses of $10 \mathrm{mg}$ aripiprazole and $5 \mathrm{mg}$ olanzapine in a crossover clinical trial were genotyped for 46 polymorphisms in 14 genes by qPCR. Drug plasma concentrations were measured by HPLC-MS/MS. Blood pressure and 12-lead ECG were measured in supine position. Adverse events were also recorded.

Results: Aripiprazole decreased diastolic blood pressure on the first day and decreased QTc on the third and fifth day. Olanzapine had a systolic and diastolic blood pressure, heart rate and QTc lowering effect on the first day. Polymorphisms in ADRA2A, COMT, DRD3 and HTR2A genes were significantly associated to these changes. The most frequent adverse drug reactions to aripiprazole were somnolence, headache, insomnia, dizziness, restlessness, palpitations, akathisia and nausea while were somnolence, dizziness, asthenia, constipation, dry mouth, headache and nausea to olanzapine. Additionally, HTR2A, HTR2C, DRD2, DRD3, OPRM1, UGT1A1 and CYP1A2 polymorphisms had a role in the development of adverse drug reactions. Conclusions: Olanzapine induced more cardiovascular changes; however, more adverse drug reactions were registered to aripiprazole. In addition, some polymorphisms may explain the difference in the incidence of these effects among subjects.

Keywords: aripiprazole, olanzapine, safety, cardiovascular effects, pharmacogenetics 
medRxiv preprint doi: https://doi.org/10.1101/2020.08.03.20167502; this version posted August 7, 2020. The copyright holder for this

preprint (which was not certified by peer review) is the author/funder, who has granted medRxiv a license to display the preprint in

All rights reserved. No reuse allowed without permission.

\section{Introduction}

Aripiprazole (ARI) and olanzapine (OLA) are atypical antipsychotics commonly prescribed for patients with schizophrenia or schizoaffective disorders (Robert R. Conley and Kelly, 2005). OLA has a higher serotonin (5-HT)2A/dopamine D2 receptor binding ratio compared to typical antipsychotics. Additionally, it has antagonistic activity at dopamine D3 and D4, 5HT3 and 5-HT6, histamine H1, $\alpha 1$-adrenergic and muscarinic M1-5 receptors (Bhana et al., 2001; Bymaster et al., 1996). On the contrary, ARI is a partial agonist at dopamine D2, D3, D4 and serotonin 5-HT1A, 5-HT2C and $\alpha 1$-adrenergic receptors and it is a 5-HT2A and 5-HT7 antagonist (Shapiro et al., 2003).

ARI is predominantly eliminated through hepatic metabolism by cytochrome P450 (CYP) isozymes 3A4 and 2D6. Its main active metabolite, dehydro-aripiprazole (DARI) has similar affinity for the dopamine D2 receptor and represents approximately $40 \%$ of ARI exposure in plasma (Kim et al., 2008). OLA is mainly metabolized by direct glucuronidation via the UDPglucuronosyltransferase (UGT) enzyme family, by oxidation via CYP1A2 and secondarily by CYP2D6 and CYP3A4 (Callaghan et al., 1999).

Several typical and atypical antipsychotics increase the risk of heart rate-corrected QT (QTc) prolongation and, as a consequence, Torsades de Pointes and sudden cardiac death (Ray et al., 2009). In previous studies with schizophrenic patients, mean QTc interval was decreased with ARI and QTc prolongation risk was lower with ARI and OLA compared to other antipsychotics (Czekalla et al., 2001; Polcwiartek et al., 2015; Ray et al., 2009; Vieweg, 2003). However, although ARI usually does no produce QTc prolongation, some studies reported the contrary in patients and healthy volunteers (Belmonte et al., 2016; Hategan and Bourgeois, 2014; Suzuki et al., 2011). Additionally, patients with impaired CYP2D6 enzyme activity (i.e. poor metabolizers, PMs) may be at a greater risk of QTc prolongation (Dorado et al., 2007).

Neuroleptic Malignant Syndrome, although it is rare, may occur with the administration of all antipsychotics. One of its symptoms is fluctuation in blood pressure (BP) (Sarkar and Gupta, 2017). Therefore, it is of emphasized importance to monitor BP during antipsychotic treatment. ARI and OLA may produce hypotension in both patients and healthy volunteers (Belmonte et al., 2016; Jana et al., 2015; Wang, 2013). Additionally, ARI can induce hypertension (YasuiFurukori and Akira Fujii, 2013). 
medRxiv preprint doi: https://doi.org/10.1101/2020.08.03.20167502; this version posted August 7, 2020. The copyright holder for this

preprint (which was not certified by peer review) is the author/funder, who has granted medRxiv a license to display the preprint in

All rights reserved. No reuse allowed without permission.

Both ARI and OLA can cause an increase in heart rate (HR) (Belmonte et al., 2016; Tajiri et al., 2018). However, when changing the therapy from OLA to ARI, a significant decrease was detected in HR (Tajiri et al., 2018). Therefore, OLA had a stronger HR increasing effect compared to ARI and it was dose-dependent (Tajiri et al., 2018).

The most common adverse drug reactions (ADRs) to ARI in schizophrenic patients are akathisia, extrapyramidal symptoms, somnolence and tremor (Ribeiro et al., 2018). On the contrary, the most common ADRs to OLA in schizophrenic patients are constipation, weight gain, dizziness, personality disorder, akathisia, postural hypotension, sedation, headache, increased appetite, fatigue, dry mouth and abdominal pain (R. R. Conley and Meltzer, 2000).

The aim of the current study was to evaluate the safety of 5 days treatment with ARI and OLA and their effects on electrocardiogram (ECG) and BP. Moreover, we aimed to correlate these factors with sex, plasma drug concentrations and genetic polymorphisms.

\section{Materials and Methods}

\section{Study Population and Design}

Twenty-four healthy volunteers (12 males and 12 females) were enrolled in a multiple oral dose, open-label, randomized, crossover, two-periods, two-sequences, single-centre, comparative, phase I clinical trial performed between June 2018-April 2019. Five doses of 10 $\mathrm{mg} /$ day ARI tablets or $5 \mathrm{mg}$ /day film-coated OLA tablets were administered to each volunteer during 5 consecutive days. Block randomization was used to assign a treatment to each volunteer on the first day. The drug was administered at 09:00 h each day under fasting conditions. After a 28 days washout period, each volunteer received the opposite drug. The random allocation sequence, the recruitment of participants and their assignment to interventions were performed by investigators of the Clinical Trials Unit.

The clinical trial was performed at the Clinical Trials Unit of our hospital. The protocol was approved by its Research Ethics Committee authorized by the Spanish Drugs Agency and under the guidelines of Good Clinical Practice and the Declaration of Helsinki (EUDRA-CT: 2018000744-26). All subjects were adequately informed about the study and, if agreeing to 
medRxiv preprint doi: https://doi.org/10.1101/2020.08.03.20167502; this version posted August 7, 2020. The copyright holder for this preprint (which was not certified by peer review) is the author/funder, who has granted medRxiv a license to display the preprint in All rights reserved. No reuse allowed without permission.

participate, signed an informed consent form before inclusion. The inclusion and exclusion criteria were reported in our previous publication (Koller, Saiz-Rodríguez, et al., 2020).

\section{Pharmacokinetic Analysis}

Twenty-two blood samples were collected in EDTA K2 tubes for pharmacokinetic assessments during each treatment period of the study. Samples were centrifuged at $3500 \mathrm{rpm}(1900 \mathrm{G})$ for 10 minutes and then plasma was collected and stored at $-80^{\circ} \mathrm{C}$ until determination of plasma concentrations by the analytical laboratory.

ARI, DARI and OLA plasma concentrations were quantified by a high-performance liquid chromatography tandem mass spectrometry (HPLC-MS/MS) method developed and validated in our laboratory (Koller et al., 2019).

The calculation of pharmacokinetic parameters was explained in our previous study (Koller, Saiz-Rodríguez, et al., 2020).

\section{Pharmacodynamic Analysis}

$\mathrm{BP}$ was measured in supine position with an automatic monitor at screening, predose, 16 times during treatment and 8 times after the last drug administration. Likewise, the 12-lead ECG was obtained at the same time points. QTc and HR were automatically calculated by the ECG device. Bazett correction formula was used to correct the QT interval (Bazett, 1997). According to the International Council for Harmonisation E14 clinical guidance (International Council on Harmonisation, 2005), a QTc interval greater than 450 milliseconds or a change from baseline greater than 30 milliseconds were considered as QTc interval prolongation.

\section{Safety and Tolerability Assessments}

Safety and tolerability of ARI was assessed by clinical evaluation of adverse events (AEs) and other parameters including vital signs, physical examinations, and 12-lead ECGs. During the development of the study, volunteers were asked if they had experienced any AE. Moreover, the Ramsay sedation scale (Ramsay et al., 1974) was evaluated 4 times/day and on each safety visit, while the UKU side effect rating scale (Lingjærde et al., 1987) was evaluated on days 2, 4, 6, 9 and 15. According to the algorithm of the Spanish Pharmacovigilance System (Aguirre and García, 2016), the causality of AEs were classified as definite, probable, possible, unlikely or unrelated. Only those AEs that were definite, probable, or possible were considered as ADRs 
medRxiv preprint doi: https://doi.org/10.1101/2020.08.03.20167502; this version posted August 7, 2020. The copyright holder for this preprint (which was not certified by peer review) is the author/funder, who has granted medRxiv a license to display the preprint in All rights reserved. No reuse allowed without permission.

for statistical analysis. Intensity (mild, moderate, and severe), time sequence and outcome of AEs were also registered.

ADRs were classified using system organ class allocation as general (asthenia, fatigue, tiredness and gait alterations), cardiovascular (palpitations), gastrointestinal (constipation, nausea, vomiting, hyposalivation, hypersalivation, dry mouth and diarrhea), nervous system (akathisia, headache, difficulties with concentration, dizziness, paraesthesia, presyncope, syncope, tremor, somnolence and restless legs), psychiatric (restlessness, insomnia, anxiety, abnormal orgasm and nightmares), respiratory (epistaxis, hiccups, cough and sore throat), endocrine (galactorrhea), metabolic (lack of appetite, increased appetite and hyporexia), reproductive (dysmenorrhea, mastalgia and menstrual irregularity), skin (hair loss, pruritus, rash and sweating), musculoskeletal (shoulder pain, knee pain, neck pain, upper limb weakness, lumbalgia, cramps, back pain and leg pain), infections (cold), eye (photophobia) and investigations (increased liver enzymes) (Brown et al., 1999).

\section{Genotyping}

DNA was extracted from $1 \mathrm{~mL}$ of peripheral blood samples using a MagNA Pure LC DNA Isolation Kit in an automatic DNA extractor (MagNa Pure ${ }^{\circledR}$ System, Roche Applied Science, Indianapolis, Indiana). Thenceforth, it was quantified spectrophotometrically in a NanoDrop ${ }^{\circledR}$ ND-1000 Spectrophotometer (Nanodrop Technologies, Wilmington, Delaware, USA) and the purity of the samples was measured by the $\mathrm{A}_{260 / 280}$ absorbance ratio.

Samples were genotyped with TaqMan assays using the OpenArray platform on a QuantStudio 12K Flex instrument (Thermo Fisher Scientific, Waltham, Massachusetts, USA). The genotyping array included 120 SNPs, whereof the following 46 were analysed in 14 genes based on their importance in the metabolism and mechanism of action of ARI and OLA: CYP1A2 *1C (rs2069514), *1F (rs762551), *1B 5347T >C (rs2470890), CYP2D6 *3 (rs35742686), *4 (rs3892097), *6 (rs5030655), *7 (rs5030867), *8 (rs5030865), *9 (rs5030656), *10 (rs1065852), *14 (rs5030865), *17 (rs28371706), *41 (rs28371725), CYP3A4 *22 (rs35599367), rs55785340, rs4646438, CYP3A5 *3 (rs776746), *6 (rs10264272), $A B C B 1$ C3435T (rs1045642), G2677 T/A (rs2032582), C1236T (rs1128503), rs3842, 1000$44 \mathrm{G}>\mathrm{T} \quad(\mathrm{rs} 10276036), 2895+3559 \mathrm{C}>\mathrm{T} \quad(\mathrm{rs} 7787082), \quad 330-3208 \mathrm{C}>\mathrm{T} \quad(\mathrm{rs} 4728709)$, $2481+788 \mathrm{~T}>\mathrm{C}(\mathrm{rs} 10248420), 2686-3393 \mathrm{~T}>\mathrm{G} \quad(\mathrm{rs} 10280101), 2320-695 \mathrm{G}>\mathrm{A} \quad(\mathrm{rs} 12720067)$, $2482-707 \mathrm{~A}>\mathrm{G} \quad(\mathrm{rs} 11983225), 2212-372 \mathrm{~A}>\mathrm{G} \quad(\mathrm{rs} 4148737), A D R A 2 A \quad \mathrm{rs} 1800544, B D N F$ 
medRxiv preprint doi: https://doi.org/10.1101/2020.08.03.20167502; this version posted August 7, 2020. The copyright holder for this preprint (which was not certified by peer review) is the author/funder, who has granted medRxiv a license to display the preprint in All rights reserved. No reuse allowed without permission.

Val66Met (rs6265), COMT rs4680, rs 13306278, DRD2 TaqIA (rs1800497), 957C > T (rs6277), -141 Ins/Del (rs1799732), DRD3 Ser9Gly (rs6280), HTR2A T102C (rs6313), C1354T (rs6314), rs7997012, HTR2C -759C/T (rs3813929), -697G/C (rs518147), rs1414334, OPRM1 rs1799971 and UGT1A1 rs887829.

Genotyping results were analysed within both the QuantStudio ${ }^{\mathrm{TM}} 12 \mathrm{~K}$ Flex and Thermo Fisher Cloud softwares (Thermo Fisher Scientific, Waltham, Massachusetts, USA). Finally, a matrix of genotypic calls was exported for each polymorphism.

CYP2D6 *29 (rs16947) polymorphism was genotyped in a 96-well thermal block installed in the same QuantStudio $12 \mathrm{~K}$ flex instrument using individual TaqMan ${ }^{\circledR}$ probes. Additionally, CYP3A4 *20 (rs67666821) polymorphism was genotyped by the KASPar SNP Genotyping System (LGC Genomics, Herts, UK). The ABI PRISM 7900HT Sequence Detection System (Thermo Fisher Scientific, Waltham, Massachusetts, USA) was used for fluorescence detection and allele assignment (Apellániz-Ruiz et al., 2015).

Copy number variations (CNVs) in the CYP2D6 gene were determined with the TaqMan ${ }^{\circledR}$ Copy Number Assay (Assay ID: Hs00010001_cn; Thermo Fisher Scientific, Waltham, Massachusetts, USA) which detects a specific sequence on exon 9. Samples were run in a 96well thermal block installed in the same QuantStudio 12K flex instrument

\section{Statistical analyses}

Statistical analyses were performed with SPSS 24.0 software (SPSS Inc., Chicago, Illinois, United States). P values lower than 0.05 were considered statistically significant. The HardyWeinberg equilibrium was estimated for all genetic variants. Deviations from the equilibrium were detected by comparing observed and expected frequencies using a Fisher exact test based on the De Finetti program (available at http://ihg.gsf.de/cgi-bin/hw/hwa1.pl). Changes in BP, HR and QTc were analysed by repeated measures ANOVA. Pharmacokinetic parameters and polymorphisms were analysed as covariates. Estimate of effect size (partial eta squared, $\eta_{\mathrm{p}}{ }^{2}$ ), i.e. the proportion of the total variance that is attributed to an effect, is reported for each ANOVA test to avoid type II errors. Chi-square test was used to compare incidence of adverse effects between different genotypes. Bonferroni post-hoc test for multiple comparisons was applied for each analysis. 
medRxiv preprint doi: https://doi.org/10.1101/2020.08.03.20167502; this version posted August 7, 2020. The copyright holder for this preprint (which was not certified by peer review) is the author/funder, who has granted medRxiv a license to display the preprint in All rights reserved. No reuse allowed without permission.

CYP2D6 *3, *4, *5, *6, *7, *8, *9, *10,*14,*17,*29 and *41 were classified in phenotypes based on the functionality of the alleles (Caudle et al., 2020; Gaedigk et al., 2008). CYP3A4 $* 2$, *20,*22, and CYP3A5*3 and *6 genotypes were merged into a CYP3A phenotype (Sanchez Spitman et al., 2017). CYP1A2*1C, *1F and *1B variants were also merged into a phenotype (Saiz-Rodríguez, Ochoa, Belmonte, et al., 2019). $A B C B 1$ variants were merged into haplotypes: 0-8 mutant alleles were assigned to group 1, 9-12 mutant alleles were assigned to group 2 and 13-17 mutant alleles were assigned to group 3. Another $A B C B 1$ haplotype was assembled by only considering C3435T, G2677T/A and C1236T polymorphisms due to greater impact on the transporter's activity or expression levels (Vivona et al., 2014). Zero or one mutant allele carriers were assigned to group 1, carriers of 2 or 3 mutant alleles were assigned to group 2 and bearing 4, 5 or 6 mutant alleles were assigned to group 3. COMT rs13306278 and rs4680 polymorphisms were merged into a haplotype: carrying no mutant allele was assigned as wild-type, carrying one mutant allele was considered as heterozygous while carrying more than one mutant allele was considered as mutant.

\section{Results}

\section{Demographic characteristics and genotype frequencies}

Demographic data are shown in Table 1. Ten subjects were Caucasian and 14 were Latin. Age was similar between males and females. Males had greater weight and height than females ( $p$ $<0.001)$, however, BMI values did not differ significantly $(p=0.798)$.

Genotype frequencies of the analysed genes are shown in Table S1.

\section{Pharmacokinetics}

Mean and standard deviation (SD) of ARI, DARI and OLA pharmacokinetic parameters are shown in Table 2. Females had lower DARI/ARI ratio than males $(p=0.046)$. The remaining pharmacokinetic parameters were not statistically different between sexes.

\section{Pharmacodynamics}

\section{Aripiprazole}

ARI had a DBP lowering effect on the first day of treatment $\left(5 \mathrm{mmHg}, p=0.004, \eta_{\mathrm{p}}{ }^{2}=0.309\right)$ and a QTc lowering effect on days 3 and $5\left(20 \mathrm{~ms}, p<0.001, \eta_{\mathrm{p}}{ }^{2}=0.512 ; 15 \mathrm{~ms}, p=0.028\right.$, $\eta_{\mathrm{p}}{ }^{2}=0.193$, respectively) (Table S2). None of the volunteers had a QTc value higher than 450 ms or showed more than a $30 \mathrm{~ms}$ change. HR incremented from predose to $5 \mathrm{~h}$ after drug administration on the $4^{\text {th }}$ day in males, while it did not change in females $\left(p=0.034, \eta_{\mathrm{p}}{ }^{2}=\right.$ 
medRxiv preprint doi: https://doi.org/10.1101/2020.08.03.20167502; this version posted August 7, 2020. The copyright holder for this preprint (which was not certified by peer review) is the author/funder, who has granted medRxiv a license to display the preprint in All rights reserved. No reuse allowed without permission.

0.197). DBP on the first day decreased more in HTR2A rs6313 C allele carriers and in $A D R A 2 A$ rs $1800544 \mathrm{C} / \mathrm{C}$ subjects compared to $\mathrm{T} / \mathrm{T}$ and $\mathrm{C} / \mathrm{G}$ subjects $\left(7 \mathrm{vs}+3 \mathrm{mmHg}, p=0.006, \eta_{\mathrm{p}}{ }^{2}=\right.$ $0.296 ; 7$ vs $0 \mathrm{mmHg}, p=0.020, \eta_{\mathrm{p}}{ }^{2}=0.224$, respectively).

\section{Olanzapine}

OLA had a SBP, DBP, HR and QTe lowering effect on the first day $5 \mathrm{~h}$ after drug administration $\left(16 \mathrm{mmHg}, p<0.001, \eta_{\mathrm{p}}{ }^{2}=0.678 ; 8 \mathrm{mmHg}, p<0.001, \eta_{\mathrm{p}}{ }^{2}=0.537 ; 10 \mathrm{bpm}, p\right.$ $<0.001, \eta_{\mathrm{p}}^{2}=0.129 ; 10 \mathrm{~ms}, p=0.002, \eta_{\mathrm{p}}^{2}=0.359$, respectively) (Table S3). None of the volunteers had a QTc value higher than $450 \mathrm{~ms}$ or showed more than a $30 \mathrm{~ms}$ change. HR increased from predose to $5 \mathrm{~h}$ after drug administration on the $4^{\text {th }}$ day in males, while it did not change in females $\left(p=0.002, \eta_{\mathrm{p}}{ }^{2}=0.350\right)$. On the $4^{\text {th }}$ day of drug administration, QTc values increased in males and the opposite effect was detected in females $\left(p=0.018, \eta_{\mathrm{p}}{ }^{2}=0.227\right)$. SBP on the first day decreased more in DRD3 rs6280 Ser/Ser and Ser/Gly and in ADRA2A rs $1800544 \mathrm{C} / \mathrm{C}$ subjects compared to volunteers with Gly/Gly and C/G genotypes (21 and 14 vs $6 \mathrm{mmHg}, p=0.025, \eta_{\mathrm{p}}{ }^{2}=0.209 ; 18$ vs $8 \mathrm{mmHg}, p=0.048, \eta_{\mathrm{p}}{ }^{2}=0.167$, respectively). Moreover, DBP on the first day diminished more in COMT wild-type subjects compared to those with heterozygous and mutant phenotype (16 vs 8 and $5 \mathrm{mmHg}, p=0.022, \eta_{\mathrm{p}}{ }^{2}=0.218$ ). Additionally, HR on the first day decreased more in DRD3 rs6280 Ser/Ser and Ser/Gly subjects compared to those with Gly/Gly genotype (16 and 15 vs $4 \mathrm{mmHg}$, respectively, $p=0.013, \eta_{\mathrm{p}}{ }^{2}$ $=0.249)$.

The effects of ARI and OLA on BP, HR and QTc are compared in Figure 1. Changes in SBP, DBP and QTc were not statistically significant between ARI and OLA ( $p=0.110, p=0.145$ and $p=0.236$, respectively). However, although it did not reach the statistically significant level, OLA lowered both SBP and DBP to a greater extent compared to ARI. After the $4^{\text {th }}$ day, tolerance was developed for the hypotensive effect of OLA. Additionally, HR was significantly lower during OLA treatment compared to ARI $\left(p<0.0001, \eta_{\mathrm{p}}{ }^{2}=0.236\right)$.

\section{Adverse drug reactions}

During the study, no serious or life-threatening AEs were documented. All volunteers experienced at least one ADR.

\section{Aripiprazole}

The most frequent ADRs were somnolence (79\%), headache (54\%), insomnia (33\%), dizziness $(21 \%)$, restlessness $(21 \%)$, palpitations $(21 \%)$, akathisia (17\%) and nausea $(17 \%)$ (Table 3$)$. 
medRxiv preprint doi: https://doi.org/10.1101/2020.08.03.20167502; this version posted August 7, 2020. The copyright holder for this preprint (which was not certified by peer review) is the author/funder, who has granted medRxiv a license to display the preprint in All rights reserved. No reuse allowed without permission.

The number of ADRs was similar between males and females $(3.9 \pm 2.3$ and $4.1 \pm 2.0 \mathrm{ADR} /$ subject, respectively). Palpitations were only registered in females ( 5 volunteers, $p=0.012$ compared to males). The incidence of akathisia was higher in DRD3 rs6280 Ser/Ser homozygotes compared to Gly allele carriers $(22.2 \%$ vs $0 \%$, respectively, $p=0.003)$. Moreover, only DRD2 rs1799732 G/- subjects experienced asthenia compared to G/G homozygotes $(33.3 \%$ vs $0 \%$, respectively, $p=0.011)$. The incidence of headache was significantly higher in HTR2C rs3813929 $\mathrm{T}$ carriers than in $\mathrm{C} / \mathrm{C}$ homozygotes $(66.7 \%$ vs $28.6 \%$, respectively, $p=0.030$ ). Additionally, an association was found between CYP1A2 $\mathrm{NM} / \mathrm{RM}$ phenotype and the incidence of insomnia (41.2\% vs $0 \%$ in $\mathrm{UM}, p=0.044$ ). Finally, somnolence was detected more frequently in HTR $2 A$ rs6314 C/C and OPRM1 rs1799971 A/A subjects compared to $\mathrm{C} / \mathrm{T}$ subjects and $\mathrm{G}$ carriers, respectively $(86.4 \%$ vs $0 \%, p=0.004$ and $89.5 \%$ vs $40 \%, p=0.029$, respectively).

\section{Olanzapine}

The most frequent ADRs were somnolence (100\%), dizziness (29\%), asthenia (13\%), constipation (13\%), dry mouth (13\%), headache (13\%) and nausea (13\%) (Table 3). The number of ADRs was similar between males and females $(1.7 \pm 1.8$ and $1.7 \pm 1.1 \mathrm{ADR} /$ subject, respectively). Constipation was detected more frequently in $H T R 2 A$ rs6314 T allele carriers, HTR2A rs7997012 A allele carriers and UGT1A1 rs887829 $\mathrm{T} / \mathrm{T}$ subjects compared to $\mathrm{C} / \mathrm{C}$ homozygotes, $\mathrm{G} / \mathrm{G}$ homozygotes and $\mathrm{C}$ allele carriers $(100.0 \%$ vs $4.5 \%, p<0.001 ; 15.4 \%$ vs $9.0 \%, p=0.026$ and $60.0 \%$ vs $0 \%, p=0.001$, respectively). Moreover, only DRD3 rs6280 Ser/Ser subjects experienced dry mouth compared to Gly allele carriers $(50.0 \%$ vs $0 \%$, respectively, $p=0.006$ ). The incidence of insomnia was higher in HTR2C rs $1414334 \mathrm{G} / \mathrm{G}$ homozygotes compared to $\mathrm{C}$ allele carriers $(100.0 \%$ vs $4.2 \%$, respectively, $p=0.003)$. In addition, nausea was only detected in HTR2C rs518147 C/T heterozygotes and not in $\mathrm{C} / \mathrm{C}$ and $\mathrm{T} / \mathrm{T}$ homozygotes $(33.3 \%$ vs $0 \%$, respectively, $p=0.038)$. Finally, palpitations were only reported in CYP1A2 UM and HTR2A rs7997012 A allele carriers and not in NM/RMs and G/G homozygotes ( $28.6 \%$ vs $0 \%, p=0.021$ and $15.4 \%$ vs $0 \%, p=0.002$, respectively).

ADRs to ARI and OLA classified by system organ class allocation are shown in Figure 2. The number of registered ADRs was significantly higher after ARI administration (91 vs 60, $p<$ 0.035). Likewise, more psychiatric and cardiac ADRs were detected during ARI treatment compared to OLA (16 vs 3 and 7 vs 2 , respectively, $p<0.001$ ). 
medRxiv preprint doi: https://doi.org/10.1101/2020.08.03.20167502; this version posted August 7, 2020. The copyright holder for this

preprint (which was not certified by peer review) is the author/funder, who has granted medRxiv a license to display the preprint in

All rights reserved. No reuse allowed without permission.

\section{Discussion}

\section{Pharmacodynamics}

\section{Effects on the blood pressure and heart rate}

ARI caused both hyper- and hypotension in previous studies. Hypertension was reported in case reports. The elevated blood pressure dropped immediately after ARI withdrawal (YasuiFurukori and Akira Fujii, 2013). In contrast, in other studies, dose-related hypotension was also reported: when ARI was reduced to $5 \mathrm{mg}$ /day (Wang, 2013) or discontinued (Torgovnick et al., 2008), the blood pressure returned to normal range. On the contrary, OLA has little effects on the cardiovascular system, if any (Khasawneh and Shankar, 2014). Nevertheless, it can cause hypotension (Lee et al., 2003). Bradycardia was also reported previously during OLA treatment (Lee et al., 2003; Markowitz et al., 2002).

In our study, ARI decreased SBP (without reaching significance) and DBP on the first day of treatment, but this effect was not repeated on the rest of the days. The BP lowering mechanism may be due to blocking the $\alpha 1$-adrenergic receptors. Moreover, its 5-HT2A antagonism could induce vasodilation and its 5-HT1A agonism could produce hypotension and bradycardia (Lin et al., 2017). Regarding OLA, SBP, DBP and HR significantly decreased after the first dose. These changes could be explained by its $\alpha 1$-adrenergic antagonism (Beasley et al., 1996). These effects were only significant on the first day of treatment and progressively diminished on the following days (Figure 1) as tolerance was developed. It was reported previously that only the first dose of OLA caused hypotension and bradycardia (Bever and Perry, 1998). Our study is the first to report this association with ARI.

SBP and DBP decreased more in $A D R A 2 A$ rs $1800544 \mathrm{C} / \mathrm{C}$ subjects compared to $\mathrm{C} / \mathrm{G}$ subjects during OLA and ARI treatment, respectively. $\alpha 2 \mathrm{~A}$-adrenergic receptors also have important roles in sympathetic cardiovascular regulation. Mice that do not express ADRA2A had increased BP and HR (Kurnik et al., 2011). Consequently, rs 1800544 mutant allele carriers should have increased BP compared to wild-type homozygotes.

DBP decreased more in HTR2A rs6313 C allele carriers compared to T/T subjects during ARI treatment. Carriers of the wild-type allele of HTR $2 A$ rs 6313 could have induced vasodilatation, and therefore a decrease in blood pressure (Lin et al., 2017). 
medRxiv preprint doi: https://doi.org/10.1101/2020.08.03.20167502; this version posted August 7, 2020. The copyright holder for this

preprint (which was not certified by peer review) is the author/funder, who has granted medRxiv a license to display the preprint in

All rights reserved. No reuse allowed without permission.

During OLA treatment, SBP and HR decreased more in DRD3 rs6280 Ser/Ser and Ser/Gly subjects compared to those with Gly/Gly genotype. Dopamine causes cardiac stimulation and therefore vasoconstriction and increase in BP. OLA blocks dopamine receptors, therefore less dopamine binds to them what can result in decreased BP and HR (Bangash et al., 2012). D3 dopamine receptor blockage depends on the genotype, what explains that carriers of the mutant genotype may have a less efficient interaction between the drug and the receptor, causing smaller variations in BP and HR.

In previous studies, COMT rs4680 A (Val, wild-type) allele carriers had lower SBP and DBP throughout the study (Ge et al., 2015; Htun et al., 2011). Our study confirmed these findings: subjects with the COMT wild-type phenotype (including COMT rs4680) had significantly higher DBP decrease after OLA administration. However, another study found the opposite: the wild-type allele was associated with SBP elevation (Hagen et al., 2007). Thus, there is no clear consensus about the role of COMT polymorphisms in its BP-lowering capacity. Nevertheless, this association could be due to its role in modulating dopamine function (Tunbridge, 2010).

Habitually, females show higher HR and QTc than males (Li et al., 2013; Lutfi and Sukkar, 2011). In our previous study both were higher in females after a single dose of ARI (Belmonte et al., 2016). In our current study we found the contrary with ARI and OLA, however, as this difference could only be seen on the $4^{\text {th }}$ day of drug administration, it may be considered an artefact.

\section{Effects on corrected QT interval}

The mean QTc interval normally decreases with ARI and the QTc prolongation risk is lower compared to other atypical antipsychotics (Polcwiartek et al., 2015). The QTc interval was overall decreased in case reports and clinical trials including schizophrenic patients and healthy volunteers, however, QTc prolongation events were also discovered (Polcwiartek et al., 2015). Our study confirms that ARI induces QTc decrease what started on the second day of drug administration and was maintained forth until the last day. Therefore, based on our results, ARI does not seem to cause QTc prolongation and consequently Torsades de Pointes and sudden cardiac death. OLA does not induce QTc prolongation (Czekalla et al., 2001). Based on the authors knowledge, the current study is the first to report QTc decrease. However, it was produced only on the first day of drug administration alike BP and HR. To date, the clinical 
medRxiv preprint doi: https://doi.org/10.1101/2020.08.03.20167502; this version posted August 7, 2020. The copyright holder for this preprint (which was not certified by peer review) is the author/funder, who has granted medRxiv a license to display the preprint in All rights reserved. No reuse allowed without permission.

significance of its QTc-shortening is uncertain. Nevertheless, it may induce proarrhythmia (Shah, 2010).

\section{Adverse drug reactions}

\section{Most common adverse drug reactions to ARI}

According to the drug label, the most common ADRs to ARI in schizophrenic patients are akathisia, extrapyramidal symptoms, somnolence and tremor (Ribeiro et al., 2018). Somnolence and akathisia were among the most frequent ADRs that we observed. The most common ADRs in clinical trials in healthy volunteers and psychotic patients were nausea, vomiting, constipation, headache, dizziness, akathisia, anxiety, insomnia, and restlessness (Ribeiro et al., 2018). All these ADRs were detected in our clinical trial in 17, 8, 13, 54, 21, $17,8,33$ and $21 \%$ of the volunteers, respectively. There is no evidence on sex differences in the prevalence of ADRs (Montero et al., 2008). Our study confirms this hypothesis. In general, the most common ADRs to ARI were nervous system and psychiatric conditions.

\section{Most common adverse drug reactions to OLA}

According to the drug label, the most common ADRs to OLA in schizophrenic patients are constipation, weight gain, dizziness, personality disorder, akathisia, postural hypotension, sedation, headache, increased appetite, fatigue, dry mouth and abdominal pain (R. R. Conley and Meltzer, 2000). Constipation, dizziness, headache and dry mouth were among the most frequent ADRs that we observed in 13, 29, 13 and 13\% of the volunteers, respectively. ADRs that we could not detect in our clinical trial were personality disorder, fatigue, sedation and abdominal pain. The absence of these findings could be due to the short treatment; the majority of these ADRs usually appear after at least 6 weeks of treatment (R. R. Conley and Meltzer, 2000). A mild weight gain was observed during our study which was reported in our previous article (Koller, Almenara, et al., 2020). There are possible sex differences in the prevalence of ADRs to OLA (Seeman, 2009). However, we did not see a difference between the two sexes in our study. The lack of association could be due to the short-time treatment and the low sample size. The most common ADRs to OLA were metabolic disorders.

\section{Cardiac disorders}

Palpitations are considered infrequent ADRs to ARI (Ribeiro et al., 2018). However, 5 female volunteers and no males experienced it in our study. Palpitations may also occur during OLA treatment, however, they are not considered as frequent ADRs (Chaves et al., 2013). Our study confirms this finding; only 2 volunteers were registered with palpitations. Interestingly, both 
medRxiv preprint doi: https://doi.org/10.1101/2020.08.03.20167502; this version posted August 7, 2020. The copyright holder for this

preprint (which was not certified by peer review) is the author/funder, who has granted medRxiv a license to display the preprint in

All rights reserved. No reuse allowed without permission.

were females, similar to ARI. We are the first to report these findings. Palpitations can be associated with arrhythmias. The proarrhythmic effect, drug-induced Torsade de Pointes occurs more frequently in females than in males (Wolbrette et al., 2002) and was observed with ARI (Polcwiartek et al., 2015), but not with OLA (Glassman and Bigger, 2001). Therefore, as in the current study, palpitations, a proarrhythmic sign, may occur more frequently in females.

In addition, during OLA treatment palpitations were only reported in CYP1A2 UMs and HTR2A rs7997012 A allele carriers. OLA is metabolized by CYP1A2 (Callaghan et al., 1999). UMs may reach high concentrations of OLA metabolites rapidly, which could be related to the development of palpitations. Additionally, palpitations were only reported in HTR2A rs 7997012 mutant (A) allele carriers. Serotonin can induce the development of palpitations (Trindade et al., 1998). Therefore, A allele carriers may have reduced 5-HTR2A blockage and consequently higher serotonin levels.

\section{Nervous system disorders}

Akathisia is commonly associated with first generation antipsychotics. It would be expected that ARI had a low incidence of akathisia being an antagonist at 5-HT2A receptors (Thomas et al., 2015). However, ARI seems to increase the risk of akathisia. Therefore, its pathophysiology seems complex, involving several neurotransmitters including dopamine, acetylcholine, $\gamma$ aminobutyric acid, norepinephrine, serotonin and neuropeptides (Iqbal et al., 2007). Consequently, DRD3 mutant (Gly) allele carriers could be more protected from developing akathisia. The fact that DRD2 rs1799732 G/- subjects experienced asthenia but not G/G homozygotes strengthens the dopamine theory: polymorphisms in its receptors seem to have a role in developing nervous system ADRs. On the contrary, OLA does not cause akathisia (Thomas et al., 2015) what was confirmed in our study. It appears that its sedating properties could be responsible for attenuating the effects of akathisia (Thomas et al., 2015).

5-HT receptors are related to the development of somnolence and headache during antipsychotic treatment, but the molecular background is unknown to date (Fang et al., 2016; LaPorta, 2007). ARI relates to a lower risk of somnolence and headache compared to other atypical antipsychotics (Fang et al., 2016), however, they are still among the most common ADRs (Ribeiro et al., 2018). Somnolence was detected more frequently in HTR2A rs6314 wildtype subjects while headache was observed more in mutant allele carriers of HTR2C 
medRxiv preprint doi: https://doi.org/10.1101/2020.08.03.20167502; this version posted August 7, 2020. The copyright holder for this preprint (which was not certified by peer review) is the author/funder, who has granted medRxiv a license to display the preprint in All rights reserved. No reuse allowed without permission.

rs3813929. Our study is the first to report these findings. It strengthens the hypothesis that 5HT receptor variability can lead to the development of these ADRs.

In our previous study, OPRM1 rs1799971 mutant (G) allele carriers were associated with the increased likelihood of somnolence to fentanyl in healthy volunteers (Saiz-Rodríguez, Ochoa, Herrador, et al., 2019). In the current study we observed the contrary: wild-type (A/A) homozygous subjects developed somnolence more frequently during ARI treatment. The G variant is reported as a protective allele against ADRs (Matic et al., 2017). However, its role in developing ADRs to ARI is currently unknown. Opioid receptor activation inhibits GABAergic interneurons in order to increase dopamine release (Hirasawa-Fujita et al., 2017). Therefore, higher dopamine concentration in OPRM1 rs1799971 wild-type homozygotes may increase the risk of somnolence.

In addition, CYP1A2 NM/RM subjects showed a higher prevalence of insomnia during ARI treatment than UM subjects. Based on current knowledge, ARI is not metabolized by CYP1A2. However, in our population, CYP1A2 UMs showed lower ARI and DARI disposition compared to the other phenotypes (Koller, Saiz-Rodríguez, et al., 2020). Therefore, NM/RM subjects were under prolonged ARI exposure what could cause the development of insomnia. Regarding OLA, insomnia is not among the most common ADRs to OLA (ZYPREXA (olanzapine), FDA., 1996). However, 2 volunteers experienced it during our study, both carrying HTR2C rs1414334 G/G genotype. The lack of serotonin can cause insomnia (Murray et al., 2015). HTR2C rs1414334 mutant (G/G) homozygotes may have less 5-HTR2C receptor blocking effect and consequently higher risk to experience insomnia.

\section{Gastrointestinal disorders}

Serotonin and acetylcholine activate the colonic smooth muscles inducing their contraction. OLA, being a 5-HT antagonist, inhibits their contraction and consequently causes constipation (Zhang et al., 2016). Carriers of HTR2A rs6314 and rs7997012 mutant alleles (T and A, respectively) displayed a higher incidence of constipation, therefore, in these subjects, OLA possibly has higher binding affinity to 5-HT2A receptors. In our previous study, the prevalence of fatigue in UGT1A1 rs887829 T/T subjects was significantly higher compared to wild-type (C) allele carriers (Cabaleiro et al., 2013). In the current study, we found the same association, but with constipation. This enzyme may be responsible for the phase II metabolism of OLA (Koller, Saiz-Rodríguez, et al., 2020). These associations were not found with ARI what we expected as it is not metabolized by the UGT enzyme family. However, similar to OLA, it is a 
medRxiv preprint doi: https://doi.org/10.1101/2020.08.03.20167502; this version posted August 7, 2020. The copyright holder for this

preprint (which was not certified by peer review) is the author/funder, who has granted medRxiv a license to display the preprint in

All rights reserved. No reuse allowed without permission.

5-HT2A antagonist. Nevertheless, this mechanism should be more complex; dopamine or other neurotransmitters could have a role in the development of constipation.

Normally, a balance is maintained between acetylcholine and dopamine. When this balance is disturbed, acetylcholine levels increase, while dopamine levels decrease (Aosaki et al., 2010). Dry mouth is an anticholinergic side effect of OLA, but not to ARI given its special mechanism of action (Bhana et al., 2001). DRD3 rs6280 wild-type (Ser/Ser) subjects may have higher dopamine level due to the low amount of acetylcholine, therefore experiencing dry mouth after OLA.

Nausea during OLA treatment was only detected in HTR2C rs518147 C/T heterozygotes and not in $\mathrm{C} / \mathrm{C}$ and $\mathrm{T} / \mathrm{T}$ homozygotes what can be due to the low sample size. This association was not found with ARI.

\section{Study limitations}

The main limitation of our study is the low sample size. Therefore, it is of importance to interpret these results with caution. Our results should be confirmed in further studies with healthy volunteers to increase the sample size as well as in schizophrenic patients to demonstrate their clinical utility. Notwithstanding, our conditions were perfectly controlled and we administered both drugs to each volunteer, what can reduce the influence of other factors, such as comorbility, smoking and nutrition. Additionally, the duration of this study was short and several ADRs to ARI and OLA could appear later than 5 days. However, the Ethics Committee would rarely authorize more than 5 days treatment with antipsychotics in healthy volunteers.

\section{Conclusions}

OLA had more cardiovascular effects than ARI. However, BP, HR and QTc decreased significantly only on the first day of drug administration. Therefore, it seems that a rapid tolerance is developed to the drug. We suggest that HTR2A, ADRA2A, DRD3 and COMT polymorphisms establish the interindividual variability of the cardiovascular effects of ARI and OLA. Contrastively, more ADRs were registered to ARI than to OLA, especially psychiatric and nervous system disorders. Additionally, we propose that HTR2A, HTR2C, DRD2, DRD3, OPRM1, UGT1A1 and CYP1A2 polymorphisms have a role in the development 
medRxiv preprint doi: https://doi.org/10.1101/2020.08.03.20167502; this version posted August 7, 2020. The copyright holder for this preprint (which was not certified by peer review) is the author/funder, who has granted medRxiv a license to display the preprint in

All rights reserved. No reuse allowed without permission.

of ADRs to ARI and OLA. Consequently, some polymorphisms may explain the difference in the incidence of ADRs among subjects.

\section{Acknowledgements}

The authors are grateful to the volunteers as well as the effort of the staff of the Clinical Trials Unit of our hospital, especially to Alejandro de Miguel-Cáceres for sample processing and Maria Hernández and Diana Campodónico for safety evaluations.

\section{Conflicts of Interest}

F. Abad-Santos and D. Ochoa have been consultants or investigators in clinical trials sponsored by the following pharmaceutical companies: Abbott, Alter, Aptatargets, Chemo, Cinfa, FAES, Farmalíder, Ferrer, Galenicum, GlaxoSmithKline, Gilead, Italfarmaco, Janssen-Cilag, Kern, Normon, Novartis, Servier, Silverpharma, Teva and Zambon. The remaining authors declare no conflict of interest.

\section{Author Contributions}

Wrote manuscript: Dora Koller; Designed research: Dora Koller, Francisco Abad-Santos, Miriam Saiz-Rodríguez, Dolores Ochoa; Performed clinical trial: Manuel Román, Gina Mejía, Francisco Abad-Santos, Daniel Romero-Palacián, Samuel Martín, Dolores Ochoa; Analysed data: Dora Koller, Susana Almenara, Gina Mejía, Francisco Abad-Santos; Determination of drug concentrations: Dora Koller, Pablo Zubiaur, Aneta Wojnicz; Pharmacogenetic assessments: Dora Koller, Pablo Zubiaur, Marcos Navares, Miriam Saiz-Rodríguez.

\section{References}

Aguirre, C., and García, M. (2016). Evaluación de la causalidad en las comunicaciones de reacciones adversas a medicamentos. Algoritmo del Sistema Español de Farmacovigilancia. Medicina Clínica, 147(10), 461-464.

https://doi.org/10.1016/j.medcli.2016.06.012

Aosaki, T., Miura, M., Suzuki, T., Nishimura, K., and Masuda, M. (2010). Acetylcholinedopamine balance hypothesis in the striatum: An update. Geriatrics \& Gerontology 
medRxiv preprint doi: https://doi.org/10.1101/2020.08.03.20167502; this version posted August 7, 2020. The copyright holder for this preprint (which was not certified by peer review) is the author/funder, who has granted medRxiv a license to display the preprint in All rights reserved. No reuse allowed without permission.

International, 10 Suppl 1, S148-157. https://doi.org/10.1111/j.14470594.2010.00588.x

Apellániz-Ruiz, M., Inglada-Pérez, L., Naranjo, M. E. G., Sánchez, L., Mancikova, V., Currás-Freixes, M., de Cubas, A. A., Comino-Méndez, I., Triki, S., Rebai, A., Rasool, M., Moya, G., Grazina, M., Opocher, G., Cascón, A., Taboada-Echalar, P., IngelmanSundberg, M., Carracedo, A., Robledo, M., ... Rodríguez-Antona, C. (2015). High frequency and founder effect of the CYP3A4*20 loss-of-function allele in the Spanish population classifies CYP3A4 as a polymorphic enzyme. The Pharmacogenomics Journal, 15(3), 288-292. https://doi.org/10.1038/tpj.2014.67

Bangash, M. N., Kong, M.-L., and Pearse, R. M. (2012). Use of inotropes and vasopressor agents in critically ill patients: Inotropes and vasopressors in the critically ill. British Journal of Pharmacology, 165(7), 2015-2033. https://doi.org/10.1111/j.14765381.2011.01588.x

Bazett, H. C. (1997). AN ANALYSIS OF THE TIME-RELATIONS OF ELECTROCARDIOGRAMS. Annals of Noninvasive Electrocardiology, 2(2), 177194. https://doi.org/10.1111/j.1542-474X.1997.tb00325.x

Beasley, C. M., Tollefson, G., Tran, P., Satterlee, W., Sanger, T., and Hamilton, S. (1996). Olanzapine versus Placebo and Haloperidol. Neuropsychopharmacology, 14(2), 111123. https://doi.org/10.1016/0893-133X(95)00069-P

Belmonte, C., Ochoa, D., Román, M., Cabaleiro, T., Talegón, M., Sánchez-Rojas, S. D., and Abad-Santos, F. (2016). Evaluation of the Relationship Between Pharmacokinetics and the Safety of Aripiprazole and Its Cardiovascular Effects in Healthy Volunteers. Journal of Clinical Psychopharmacology, 36(6), 608-614. https://doi.org/10.1097/JCP.0000000000000577 
medRxiv preprint doi: https://doi.org/10.1101/2020.08.03.20167502; this version posted August 7, 2020. The copyright holder for this

preprint (which was not certified by peer review) is the author/funder, who has granted medRxiv a license to display the preprint in

All rights reserved. No reuse allowed without permission.

Bever, K. A., and Perry, P. J. (1998). Olanzapine: A serotonin-dopamine-receptor antagonist for antipsychotic therapy. American Journal of Health-System Pharmacy, 55(10), 1003-1016. https://doi.org/10.1093/ajhp/55.10.1003

Bhana, N., Foster, R. H., Olney, R., and Plosker, G. L. (2001). Olanzapine: An updated review of its use in the management of schizophrenia. Drugs, 61(1), 111-161.

Brown, E. G., Wood, L., and Wood, S. (1999). The medical dictionary for regulatory activities (MedDRA). Drug Safety, 20(2), 109-117.

https://doi.org/10.2165/00002018-199920020-00002

Bymaster, F. P., Calligaro, D. O., Falcone, J. F., Marsh, R. D., Moore, N. A., Tye, N. C., Seeman, P., and Wong, D. T. (1996). Radioreceptor Binding Profile of the Atypical Antipsychotic Olanzapine. Neuropsychopharmacology, 14(2), 87-96. https://doi.org/10.1016/0893-133X(94)00129-N

Cabaleiro, T., López-Rodríguez, R., Ochoa, D., Román, M., Novalbos, J., and Abad-Santos, F. (2013). Polymorphisms influencing olanzapine metabolism and adverse effects in healthy subjects. Human Psychopharmacology, 28(3), 205-214.

https://doi.org/10.1002/hup.2308

Callaghan, J. T., Bergstrom, R. F., Ptak, L. R., and Beasley, C. M. (1999). Olanzapine.

Pharmacokinetic and pharmacodynamic profile. Clinical Pharmacokinetics, 37(3), 177-193. https://doi.org/10.2165/00003088-199937030-00001

Caudle, K. E., Sangkuhl, K., Whirl-Carrillo, M., Swen, J. J., Haidar, C. E., Klein, T. E., Gammal, R. S., Relling, M. V., Scott, S. A., Hertz, D. L., Guchelaar, H.-J., and Gaedigk, A. (2020). Standardizing CYP2D6 Genotype to Phenotype Translation: Consensus Recommendations from the Clinical Pharmacogenetics Implementation Consortium and Dutch Pharmacogenetics Working Group. Clinical and Translational Science, 13(1), 116-124. https://doi.org/10.1111/cts.12692 
medRxiv preprint doi: https://doi.org/10.1101/2020.08.03.20167502; this version posted August 7, 2020. The copyright holder for this

preprint (which was not certified by peer review) is the author/funder, who has granted medRxiv a license to display the preprint in

All rights reserved. No reuse allowed without permission.

Chaves, K. M., Serrano-Blanco, A., Ribeiro, S. B., Soares, L. A. L., Guerra, G. C. B., do Socorro Costa Feitosa Alves, M., de Araújo Júnior, R. F., de Paula Soares Rachetti, V., Filgueira Júnior, A., and de Araújo, A. A. (2013). Quality of Life and Adverse Effects of Olanzapine Versus Risperidone Therapy in Patients with Schizophrenia. Psychiatric Quarterly, 84(1), 125-135. https://doi.org/10.1007/s11126-012-9233-3

Conley, R. R., and Meltzer, H. Y. (2000). Adverse events related to olanzapine. The Journal of Clinical Psychiatry, 61 Suppl 8, 26-29; discussion 30.

Conley, Robert R., and Kelly, D. L. (2005). Second-generation antipsychotics for schizophrenia: A review of clinical pharmacology and medication-associated side effects. The Israel Journal of Psychiatry and Related Sciences, 42(1), 51-60.

Czekalla, J., Beasley, C. M., Dellva, M. A., Berg, P. H., and Grundy, S. (2001). Analysis of the QTc interval during olanzapine treatment of patients with schizophrenia and related psychosis. The Journal of Clinical Psychiatry, 62(3), 191-198.

Dorado, P., Berecz, R., Peñas-LLedó, E. M., and LLerena, A. (2007). Antipsychotic drugs and QTc prolongation: The potential role of CYP2D6 genetic polymorphism. Expert Opinion on Drug Metabolism \& Toxicology, 3(1), 9-19.

https://doi.org/10.1517/17425255.3.1.9

Fang, F., Sun, H., Wang, Z., Ren, M., Calabrese, J. R., and Gao, K. (2016). Antipsychotic Drug-Induced Somnolence: Incidence, Mechanisms, and Management. CNS Drugs, 30(9), 845-867. https://doi.org/10.1007/s40263-016-0352-5

Gaedigk, A., Simon, S. D., Pearce, R. E., Bradford, L. D., Kennedy, M. J., and Leeder, J. S. (2008). The CYP2D6 activity score: Translating genotype information into a qualitative measure of phenotype. Clinical Pharmacology and Therapeutics, 83(2), 234-242. https://doi.org/10.1038/sj.clpt.6100406 
medRxiv preprint doi: https://doi.org/10.1101/2020.08.03.20167502; this version posted August 7, 2020. The copyright holder for this

preprint (which was not certified by peer review) is the author/funder, who has granted medRxiv a license to display the preprint in

All rights reserved. No reuse allowed without permission.

Ge, L., Wu, H.-Y., Pan, S.-L., Huang, L., Sun, P., Liang, Q.-H., Pang, G.-F., Lv, Z.-P., Hu, C.-Y., Liu, C.-W., Zhou, X.-L., Huang, L.-J., Yin, R.-X., and Peng, J.-H. (2015).

COMT Val158Met polymorphism is associated with blood pressure and lipid levels in general families of Bama longevous area in China. International Journal of Clinical and Experimental Pathology, 8(11), 15055-15064.

Glassman, A. H., and Bigger, J. T. (2001). Antipsychotic Drugs: Prolonged QTc Interval, Torsade de Pointes, and Sudden Death. American Journal of Psychiatry, 158(11), 1774-1782. https://doi.org/10.1176/appi.ajp.158.11.1774

Hagen, K., Pettersen, E., Stovner, L. J., Skorpen, F., Holmen, J., and Zwart, J.-A. (2007). High systolic blood pressure is associated with Val/Val genotype in the catechol-omethyltransferase gene. The Nord-Trøndelag Health Study (HUNT). American Journal of Hypertension, 20(1), 21-26.

https://doi.org/10.1016/j.amjhyper.2006.05.023

Hategan, A., and Bourgeois, J. A. (2014). Aripiprazole-Associated QTc Prolongation in a Geriatric Patient: Journal of Clinical Psychopharmacology, 34(6), 766-768. https://doi.org/10.1097/JCP.0000000000000213

Hirasawa-Fujita, M., Bly, M. J., Ellingrod, V. L., Dalack, G. W., and Domino, E. F. (2017). Genetic Variation of the Mu Opioid Receptor (OPRM1) and Dopamine D2 Receptor (DRD2) is Related to Smoking Differences in Patients with Schizophrenia but not Bipolar Disorder. Clinical Schizophrenia \& Related Psychoses, 11(1), 39-48. https://doi.org/10.3371/1935-1232-11.1.39

Htun, N. C., Miyaki, K., Song, Y., Ikeda, S., Shimbo, T., and Muramatsu, M. (2011). Association of the Catechol-O-Methyl Transferase Gene Val158Met Polymorphism With Blood Pressure and Prevalence of Hypertension: Interaction With Dietary 
medRxiv preprint doi: https://doi.org/10.1101/2020.08.03.20167502; this version posted August 7, 2020. The copyright holder for this preprint (which was not certified by peer review) is the author/funder, who has granted medRxiv a license to display the preprint in All rights reserved. No reuse allowed without permission.

Energy Intake. American Journal of Hypertension, 24(9), 1022-1026.

https://doi.org/10.1038/ajh.2011.93

International Council on Harmonisation. (2005). The Clinical Evaluation of QT/QTc Interval Prolongation and Proarrhythmic Potential for Non-Antiarrhythmic Drugs.

Iqbal, N., Lambert, T., and Masand, P. (2007). Akathisia: Problem of History or Concern of Today. CNS Spectrums, 12(S14), 1-16. https://doi.org/10.1017/S1092852900026201

Jana, A. K., Praharaj, S. K., and Roy, N. (2015). Olanzapine-induced Orthostatic Hypotension. Clinical Psychopharmacology and Neuroscience, 13(1), 113-114. https://doi.org/10.9758/cpn.2015.13.1.113

Khasawneh, F. T., and Shankar, G. S. (2014). Minimizing Cardiovascular Adverse Effects of Atypical Antipsychotic Drugs in Patients with Schizophrenia. Cardiology Research and Practice, 2014, 1-8. https://doi.org/10.1155/2014/273060

Kim, J.-R., Seo, H.-B., Cho, J.-Y., Kang, D.-H., Kim, Y. K., Bahk, W.-M., Yu, K.-S., Shin, S.-G., Kwon, J. S., and Jang, I.-J. (2008). Population pharmacokinetic modelling of aripiprazole and its active metabolite, dehydroaripiprazole, in psychiatric patients. British Journal of Clinical Pharmacology, 66(6), 802-810. https://doi.org/10.1111/j.1365-2125.2008.03223.x

Koller, D., Almenara, S., Mejía, G., Saiz-Rodríguez, M., Zubiaur, P., Román, M., Ochoa, D., Navares, M., Santos, E., Pintos, E., and Abad-Santos, F. (2020). Metabolic effects of aripiprazole and olanzapine multiple-dose treatment in healthy volunteers. Association with pharmacogenetics.

Koller, D., Saiz-Rodríguez, M., Zubiaur, P., Ochoa, D., Almenara, S., Román, M., RomeroPalacián, D., de Miguel-Cáceres, A., Martín, S., Navares, M., Mejía, G., Wojnicz, A., and Abad-Santos, F. (2020). The effects of aripiprazole and olanzapine on pupillary 
medRxiv preprint doi: https://doi.org/10.1101/2020.08.03.20167502; this version posted August 7, 2020. The copyright holder for this preprint (which was not certified by peer review) is the author/funder, who has granted medRxiv a license to display the preprint in All rights reserved. No reuse allowed without permission.

light reflex and its relationship with pharmacogenetics in a randomised multiple-dose trial. British Journal of Clinical Pharmacology. https://doi.org/10.1111/bcp.14300

Koller, D., Zubiaur, P., Saiz-Rodríguez, M., Abad-Santos, F., and Wojnicz, A. (2019). Simultaneous determination of six antipsychotics, two of their metabolites and caffeine in human plasma by LC-MS/MS using a phospholipid-removal microelutionsolid phase extraction method for sample preparation. Talanta, 198, 159-168. https://doi.org/10.1016/j.talanta.2019.01.112

Kurnik, D., Muszkat, M., Li, C., Sofowora, G. G., Friedman, E. A., Scheinin, M., Wood, A. J. J., and Stein, C. M. (2011). Genetic variations in the $\alpha(2 \mathrm{~A})$-adrenoreceptor are associated with blood pressure response to the agonist dexmedetomidine. Circulation. Cardiovascular Genetics, 4(2), 179-187.

https://doi.org/10.1161/CIRCGENETICS.110.957662

LaPorta, L. D. (2007). Relief From Migraine Headache With Aripiprazole Treatment. Headache: The Journal of Head and Face Pain, 47(6), 922-926. https://doi.org/10.1111/j.1526-4610.2007.00777.x

Lee, T.-W., Tsai, S.-J., and Hwang, J.-P. (2003). Severe Cardiovascular Side Effects of Olanzapine in an Elderly Patient: Case Report. The International Journal of Psychiatry in Medicine, 33(4), 399-401. https://doi.org/10.2190/U99G-XDML0GRG-BYE0

Li, G., Cheng, G., Wu, J., Zhou, X., Liu, P., and Sun, C. (2013). Drug-Induced Long QT Syndrome in Women. Advances in Therapy, 30(9), 793-802. https://doi.org/10.1007/s12325-013-0056-X

Lin, Y.-S., Ho, P.-S., and Liang, C.-S. (2017). Severe orthostatic hypotension after adding low-dose aripiprazole to clozapine. Archives of Clinical Psychiatry (São Paulo), 44(3), 84-84. https://doi.org/10.1590/0101-60830000000125 
medRxiv preprint doi: https://doi.org/10.1101/2020.08.03.20167502; this version posted August 7, 2020. The copyright holder for this

preprint (which was not certified by peer review) is the author/funder, who has granted medRxiv a license to display the preprint in

All rights reserved. No reuse allowed without permission.

Lingjærde, O., Ahlfors, U. G., Bech, P., Dencker, S. J., and Elgen, K. (1987). The UKU side effect rating scale: A new comprehensive rating scale for psychotropic drugs and a cross-sectional study of side effects in neuroleptic-treated patients. Acta Psychiatrica Scandinavica, 76(s334), 1-100. https://doi.org/10.1111/j.1600-0447.1987.tb10566.x

Lutfi, M. F., and Sukkar, M. Y. (2011). The effect of gender on heart rate variability in asthmatic and normal healthy adults. International Journal of Health Sciences, 5(2), $146-154$.

Markowitz, J. S., DeVane, C. L., Boulton, D. W., Liston, H. L., and Risch, S. C. (2002). Hypotension and Bradycardia in a Healthy Volunteer following a Single $5 \mathrm{mg}$ Dose of Olanzapine. The Journal of Clinical Pharmacology, 42(1), 104-106.

https://doi.org/10.1177/0091270002042001013

Matic, M., de Wildt, S. N., Tibboel, D., and van Schaik, R. H. N. (2017). Analgesia and Opioids: A Pharmacogenetics Shortlist for Implementation in Clinical Practice. Clinical Chemistry, 63(7), 1204-1213. https://doi.org/10.1373/clinchem.2016.264986 Montero, I., Talavera, M., and Ruiz, I. (2008). Clinical trials with a new atypical antipsychotic (Aripiprazole): Gender specific information analysis. Women \& Health, 47(4), 39-51. https://doi.org/10.1080/03630240802100051

Murray, N. M., Buchanan, G. F., and Richerson, G. B. (2015). Insomnia Caused by Serotonin Depletion is Due to Hypothermia. Sleep, 38(12), 1985-1993. https://doi.org/10.5665/sleep.5256

Polcwiartek, C., Sneider, B., Graff, C., Taylor, D., Meyer, J., Kanters, J. K., and Nielsen, J. (2015). The cardiac safety of aripiprazole treatment in patients at high risk for torsade: A systematic review with a meta-analytic approach. Psychopharmacology, 232(18), 3297-3308. https://doi.org/10.1007/s00213-015-4024-9 
medRxiv preprint doi: https://doi.org/10.1101/2020.08.03.20167502; this version posted August 7, 2020. The copyright holder for this

preprint (which was not certified by peer review) is the author/funder, who has granted medRxiv a license to display the preprint in

All rights reserved. No reuse allowed without permission.

Ramsay, M. A. E., Savege, T. M., Simpson, B. R. J., and Goodwin, R. (1974). Controlled

Sedation with Alphaxalone-Alphadolone. BMJ, 2(5920), 656-659.

https://doi.org/10.1136/bmj.2.5920.656

Ray, W. A., Chung, C. P., Murray, K. T., Hall, K., and Stein, C. M. (2009). Atypical

Antipsychotic Drugs and the Risk of Sudden Cardiac Death. New England Journal of

Medicine, 360(3), 225-235. https://doi.org/10.1056/NEJMoa0806994

Ribeiro, E. L. A., de Mendonça Lima, T., Vieira, M. E. B., Storpirtis, S., and Aguiar, P. M.

(2018). Efficacy and safety of aripiprazole for the treatment of schizophrenia: An overview of systematic reviews. European Journal of Clinical Pharmacology, 74(10), 1215-1233. https://doi.org/10.1007/s00228-018-2498-1

Saiz-Rodríguez, M., Ochoa, D., Belmonte, C., Román, M., Vieira de Lara, D., Zubiaur, P., Koller, D., Mejía, G., and Abad-Santos, F. (2019). Polymorphisms in CYP1A2, CYP2C9 and ABCB1 affect agomelatine pharmacokinetics. Journal of Psychopharmacology (Oxford, England), 33(4), 522-531. https://doi.org/10.1177/0269881119827959

Saiz-Rodríguez, M., Ochoa, D., Herrador, C., Belmonte, C., Román, M., Alday, E., Koller, D., Zubiaur, P., Mejía, G., Hernández-Martínez, M., and Abad-Santos, F. (2019). Polymorphisms associated with fentanyl pharmacokinetics, pharmacodynamics and adverse effects. Basic \& Clinical Pharmacology \& Toxicology, 124(3), 321-329. https://doi.org/10.1111/bcpt.13141

Sanchez Spitman, A. B., Moes, D. J. A. R., Gelderblom, H., Dezentje, V. O., Swen, J. J., and Guchelaar, H. J. (2017). Effect of CYP3A4*22, CYP3A5*3, and CYP3A combined genotypes on tamoxifen metabolism. European Journal of Clinical Pharmacology, 73(12), 1589-1598. https://doi.org/10.1007/s00228-017-2323-2 
medRxiv preprint doi: https://doi.org/10.1101/2020.08.03.20167502; this version posted August 7, 2020. The copyright holder for this

preprint (which was not certified by peer review) is the author/funder, who has granted medRxiv a license to display the preprint in

All rights reserved. No reuse allowed without permission.

Sarkar, S., and Gupta, N. (2017). Drug information update. Atypical antipsychotics and neuroleptic malignant syndrome: Nuances and pragmatics of the association. BJPsych Bulletin, 41(4), 211-216. https://doi.org/10.1192/pb.bp.116.053736

Seeman, M. V. (2009). Secondary Effects of Antipsychotics: Women at Greater Risk Than Men. Schizophrenia Bulletin, 35(5), 937-948. https://doi.org/10.1093/schbul/sbn023

Shah, R. R. (2010). Drug-induced QT interval shortening: Potential harbinger of proarrhythmia and regulatory perspectives: Drugs, QT shortening and regulatory perspectives. British Journal of Pharmacology, 159(1), 58-69. https://doi.org/10.1111/j.1476-5381.2009.00191.x

Shapiro, D. A., Renock, S., Arrington, E., Chiodo, L. A., Liu, L.-X., Sibley, D. R., Roth, B. L., and Mailman, R. (2003). Aripiprazole, A Novel Atypical Antipsychotic Drug with a Unique and Robust Pharmacology. Neuropsychopharmacology, 28(8), 1400-1411. https://doi.org/10.1038/sj.npp.1300203

Suzuki, Y., Ono, S., Fukui, N., Sugai, T., Watanabe, J., Tsuneyama, N., and Someya, T. (2011). Dose-dependent increase in the QTc interval in aripiprazole treatment after risperidone. Progress in Neuro-Psychopharmacology and Biological Psychiatry, 35(2), 643-644. https://doi.org/10.1016/j.pnpbp.2010.10.024

Tajiri, M., Suzuki, Y., Sugai, T., Tsuneyama, N., and Someya, T. (2018). Effects of olanzapine on resting heart rate in Japanese patients with schizophrenia. PLOS ONE, 13(7), e0199922. https://doi.org/10.1371/journal.pone.0199922

Thomas, J. E., Caballero, J., and Harrington, C. A. (2015). The Incidence of Akathisia in the Treatment of Schizophrenia with Aripiprazole, Asenapine and Lurasidone: A MetaAnalysis. Current Neuropharmacology, 13(5), 681-691. https://doi.org/10.2174/1570159x13666150115220221 
medRxiv preprint doi: https://doi.org/10.1101/2020.08.03.20167502; this version posted August 7, 2020. The copyright holder for this

preprint (which was not certified by peer review) is the author/funder, who has granted medRxiv a license to display the preprint in

All rights reserved. No reuse allowed without permission.

Torgovnick, J., Sethi, N. K., and Arsura, E. (2008). Aripiprazole-induced orthostatic hypotension and cardiac arrhythmia. Psychiatry and Clinical Neurosciences, 62(4), 485. https://doi.org/10.1111/j.1440-1819.2008.01833.x

Trindade, E., Menon, D., Topfer, L. A., and Coloma, C. (1998). Adverse effects associated with selective serotonin reuptake inhibitors and tricyclic antidepressants: A metaanalysis. CMAJ: Canadian Medical Association Journal = Journal de l'Association Medicale Canadienne, 159(10), 1245-1252.

Tunbridge, E. M. (2010). The catechol-O-methyltransferase gene: Its regulation and polymorphisms. International Review of Neurobiology, 95, 7-27. https://doi.org/10.1016/B978-0-12-381326-8.00002-8

Vieweg, W. V. (2003). New Generation Antipsychotic Drugs and QTc Interval Prolongation. Primary Care Companion to the Journal of Clinical Psychiatry, 5(5), 205-215. https://doi.org/10.4088/pcc.v05n0504

Vivona, D., Lima, L. T., Rodrigues, A. C., Bueno, C. T., Alcantara, G. K. S., Barros, L. S. R., De Moraes Hungria, V. T., Chiattone, C. S., De Lourdes Lopes Ferrari Chauffaille, M., and Guerra-Shinohara, E. M. (2014). ABCB1 haplotypes are associated with P-gp activity and affect a major molecular response in chronic myeloid leukemia patients treated with a standard dose of imatinib. Oncology Letters, 7(4), 1313-1319. https://doi.org/10.3892/ol.2014.1857

Wang, Y.-C. (2013). Dose-Related Reversible Hypotension During Aripiprazole Treatment. The Journal of Neuropsychiatry and Clinical Neurosciences, 25(1), E33-E33. https://doi.org/10.1176/appi.neuropsych.12030046

Wolbrette, D., Naccarelli, G., Curtis, A., Lehmann, M., and Kadish, A. (2002). Gender differences in arrhythmias. Clinical Cardiology, 25(2), 49-56. https://doi.org/10.1002/clc.4950250203 
medRxiv preprint doi: https://doi.org/10.1101/2020.08.03.20167502; this version posted August 7, 2020. The copyright holder for this preprint (which was not certified by peer review) is the author/funder, who has granted medRxiv a license to display the preprint in All rights reserved. No reuse allowed without permission.

Yasui-Furukori, N., and Akira Fujii. (2013). Worsened hypertension control induced by aripiprazole. Neuropsychiatric Disease and Treatment, 505.

https://doi.org/10.2147/NDT.S43950

Zhang, J., Qiao, Y., Le, J., Sun, D., Guan, Y., and Li, Z. (2016). Olanzapine May Inhibit Colonic Motility Associated with the 5-HT Receptor and Myosin Light Chain Kinase. Psychiatry Investigation, 13(2), 232-238. https://doi.org/10.4306/pi.2016.13.2.232 ZYPREXA (olanzapine), FDA. (1996). ZYPREXA (olanzapine). HIGHLIGHTS OF PRESCRIBING INFORMATION. U S Food and Drug Administration. http://pi.lilly.com/us/zyprexa_relprevv.pdf
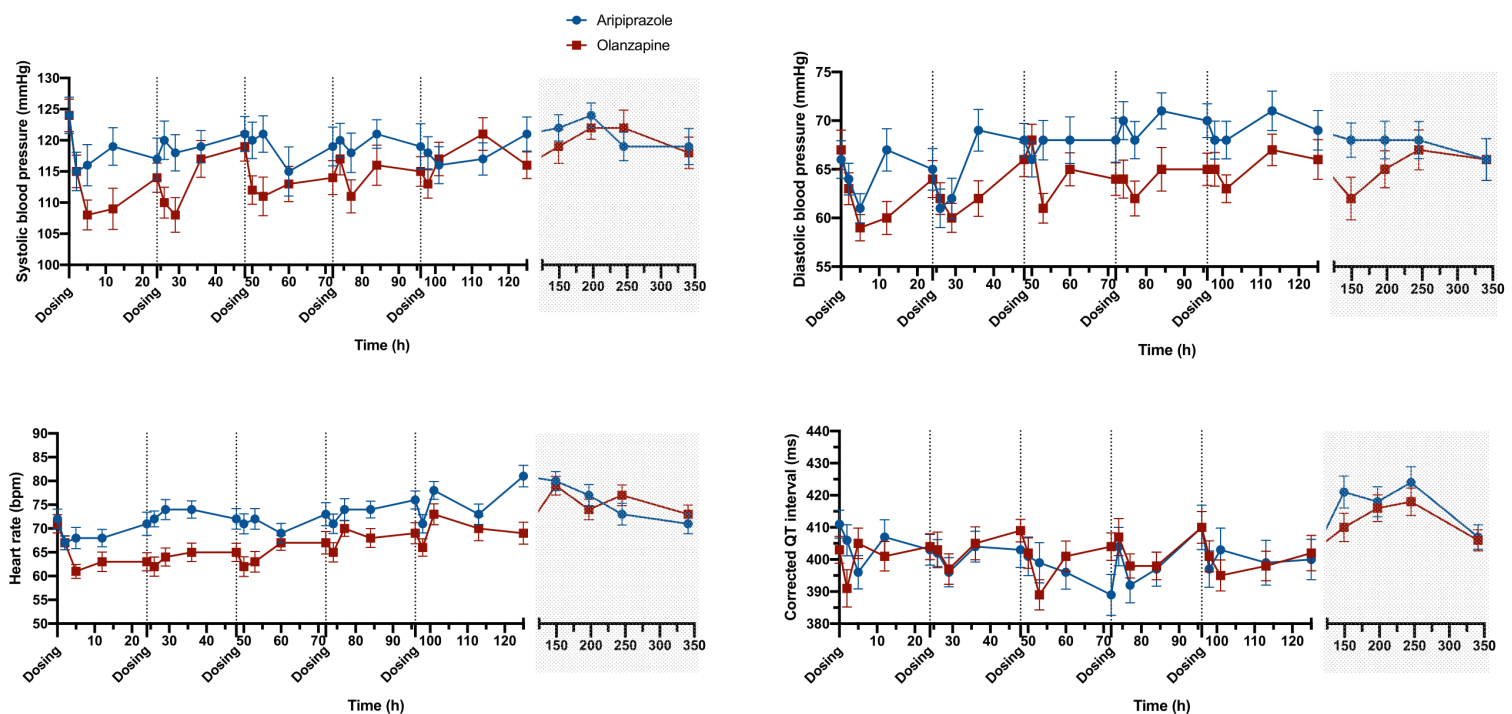

Figure 1. Effects of aripiprazole and olanzapine on blood pressure, heart rate and corrected QT interval.

The shaded section shows the values after the end of treatment. The results are shown in mean \pm SD. 
medRxiv preprint doi: https://doi.org/10.1101/2020.08.03.20167502; this version posted August 7, 2020. The copyright holder for this preprint (which was not certified by peer review) is the author/funder, who has granted medRxiv a license to display the preprint in All rights reserved. No reuse allowed without permission.

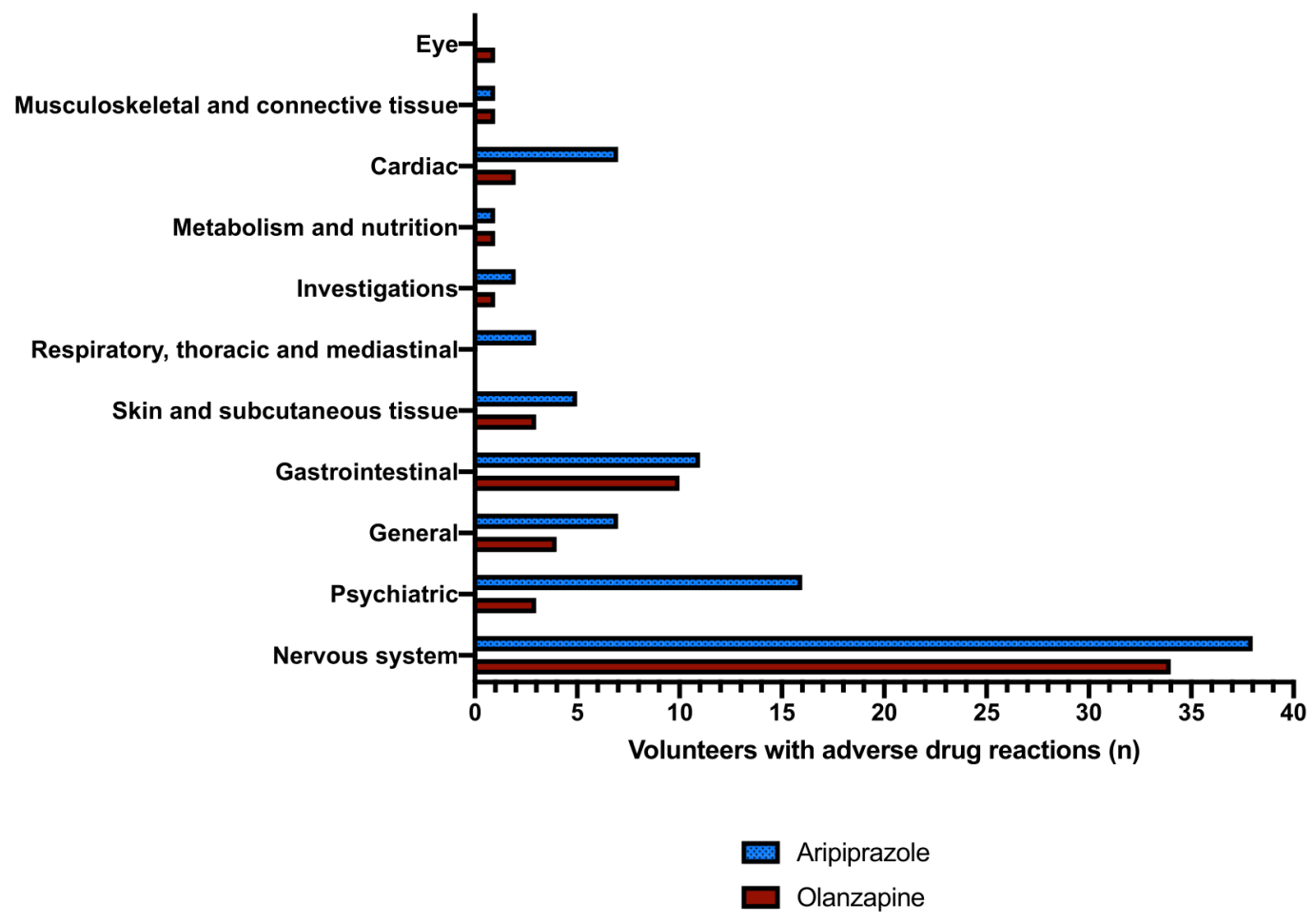

Figure 2. Adverse drug reactions to aripiprazole and olanzapine classified in groups.

Table 1. Demographic characteristics.

\begin{tabular}{c|ccccc} 
& N (\%) & Age (y) & Weight (kg) & Height (m) & BMI (kg/m²) \\
\hline All & $24(100)$ & $31.5 \pm 11.6$ & $71.4 \pm 12.2$ & $1.68 \pm 0.11$ & $25.3 \pm 2.6$ \\
Males & $12(50)$ & $28.5 \pm 7.4$ & $78.4 \pm 12.2$ & $1.76 \pm 0.09$ & $25.4 \pm 2.8$ \\
Females & $12(50)$ & $34.6 \pm 14.3$ & $64.3 \pm 7.4^{*}$ & $1.60 \pm 0.07^{*}$ & $25.1 \pm 2.5$
\end{tabular}

Values are shown as mean \pm SD unless otherwise indicated. $* p<0.05$ versus males. 
medRxiv preprint doi: https://doi.org/10.1101/2020.08.03.20167502; this version posted August 7, 2020. The copyright holder for this preprint (which was not certified by peer review) is the author/funder, who has granted medRxiv a license to display the preprint in perpetuity.

All rights reserved. No reuse allowed without permission.

Table 2. Pharmacokinetic parameters of aripiprazole, dehydro-aripiprazole and olanzapine after 5 days administration of aripiprazole $10 \mathrm{mg}$ /day or olanzapine $5 \mathrm{mg} /$ day.

\begin{tabular}{|c|c|c|c|}
\hline ARIPIPRAZOLE & All & Males & Females \\
\hline $\operatorname{AUC}_{\text {INF }}(\mathbf{n g} \cdot \mathbf{h} / \mathbf{m L})$ & $11102.4 \pm 8234.0$ & $7789.1 \pm 4071.5$ & $14415.7 \pm 10061.4$ \\
\hline $\mathrm{C}_{\text {MAX }}(\mathrm{ng} / \mathrm{mL})$ & $137.94 \pm 45.92$ & $129.6 \pm 47.4$ & $146.3 \pm 44.9$ \\
\hline DEHYDRO-ARIPIPRAZOLE & All & Males & Females \\
\hline $\operatorname{AUC}_{24 \mathrm{H}}(\mathrm{ng} \cdot \mathbf{h} / \mathrm{mL})$ & $5149.8 \pm 1628.6$ & $4721.3 \pm 1670.3$ & $5578.3 \pm 1534.8$ \\
\hline $\mathrm{C}_{\text {MAX }}(\mathrm{ng} / \mathrm{mL})$ & $34.88 \pm 8.45$ & $35.62 \pm 9.62$ & $34.13 \pm 7.45$ \\
\hline $\begin{array}{c}\text { ARIPIPRAZOLE }+ \\
\text { DEHYDRO-ARIPIPRAZOLE }\end{array}$ & All & Males & Females \\
\hline $\operatorname{AUC}(\mathbf{n g} \cdot \mathbf{h} / \mathbf{m L})$ & $14596.1 \pm 6639.1$ & $11883.5 \pm 4788.9$ & $17308.6 \pm 7292.2$ \\
\hline $\mathrm{C}_{\text {MAX }}(\mathrm{ng} / \mathrm{mL})$ & $172.82 \pm 48.74$ & $165.27 \pm 53.98$ & $180.38 \pm 43.93$ \\
\hline AUC RATIO & $0.64 \pm 0.25$ & $0.74 \pm 0.27$ & $0.54 \pm 0.20^{*}$ \\
\hline C $_{\text {MAX }}$ RATIO & $0.27 \pm 0.08$ & $0.29 \pm 0.07$ & $0.25 \pm 0.09$ \\
\hline OLANZAPINE & All & Males & Females \\
\hline $\operatorname{AUC}_{\text {INF }}(n g \cdot h / m L)$ & $1289.4 \pm 370.1$ & $1142.7 \pm 291.2$ & $1436.2 \pm 393.1$ \\
\hline$C_{\text {MAX }}(n g / m L)$ & $19.10 \pm 4.77$ & $18.35 \pm 4.04$ & $19.85 \pm 5.48$ \\
\hline
\end{tabular}

$* \mathrm{P} \leq 0.05$ versus males.

Values are shown as mean $\pm \mathrm{SD}$.

Abbreviations: $\mathrm{C}_{\max }$ : maximum plasma concentration; $\mathrm{AUC}_{\mathrm{inf}}$ : area under the curve from zero to infinity; $\mathrm{AUC}_{24 \mathrm{~h}}$ : area under the curve over $24 \mathrm{~h}$; AUC ratio: dehydro-aripiprazole/aripiprazole AUC ratio; $\mathrm{C}_{\max }$ ratio: dehydro-aripiprazole/ aripiprazole $\mathrm{C}_{\max }$ ratio. 
medRxiv preprint doi: https://doi.org/10.1101/2020.08.03.20167502; this version posted August 7, 2020. The copyright holder for this preprint (which was not certified by peer review) is the author/funder, who has granted medRxiv a license to display the preprint in All rights reserved. No reuse allowed without permission.

Table 3. Adverse drug reactions to aripiprazole and olanzapine.

\begin{tabular}{|c|c|c|}
\hline Adverse event & $\begin{array}{l}\text { Aripiprazole } \\
\qquad \mathbf{N}(\%)\end{array}$ & $\begin{array}{c}\text { Olanzapine } \\
\text { N (\%) }\end{array}$ \\
\hline \multicolumn{3}{|l|}{ Nervous system disorders } \\
\hline Akathisia & $4(17)$ & - \\
\hline Dizziness & $5(21)$ & $7(29)$ \\
\hline Headache & $13(54)$ & $3(13)$ \\
\hline Restless legs & $1(4)$ & - \\
\hline Somnolence & $19(79)$ & $24(100)$ \\
\hline Pre-syncope & - & $1(4)$ \\
\hline Syncope & $1(4)$ & $1(4)$ \\
\hline Left hand tremor & - & $1(4)$ \\
\hline \multicolumn{3}{|l|}{ Psychiatric disorders } \\
\hline Anxiety & $2(8)$ & - \\
\hline Early awakening & $1(4)$ & - \\
\hline Restlessness & $5(21)$ & $1(4)$ \\
\hline Insomnia & $8(33)$ & $2(8)$ \\
\hline \multicolumn{3}{|l|}{ General disorders } \\
\hline Asthenia & $2(8)$ & $3(13)$ \\
\hline Fatigue & $2(8)$ & - \\
\hline Gait alterations & $1(4)$ & - \\
\hline Tiredness & $1(4)$ & - \\
\hline Weakness & $1(4)$ & $1(4)$ \\
\hline \multicolumn{3}{|l|}{ Gastrointestinal disorders } \\
\hline Constipation & $3(13)$ & $3(13)$ \\
\hline Dry mouth & - & $3(13)$ \\
\hline Gastric discomfort & $1(4)$ & - \\
\hline Hypersalivation & - & $1(4)$ \\
\hline Hyposalivation & $1(4)$ & - \\
\hline Nausea & $4(17)$ & $3(13)$ \\
\hline Vomiting & $2(8)$ & - \\
\hline \multicolumn{3}{|c|}{ Skin and subcutaneous tissue disorders } \\
\hline Facial rash & $1(4)$ & $1(4)$ \\
\hline Hair loss & $1(4)$ & - \\
\hline Rash & - & $1(4)$ \\
\hline
\end{tabular}


medRxiv preprint doi: https://doi.org/10.1101/2020.08.03.20167502; this version posted August 7, 2020. The copyright holder for this preprint (which was not certified by peer review) is the author/funder, who has granted medRxiv a license to display the preprint in perpetuity.

All rights reserved. No reuse allowed without permission.

\begin{tabular}{|c|c|c|}
\hline Sweating & $3(13)$ & - \\
\hline Pruritus & - & $1(4)$ \\
\hline \multicolumn{3}{|c|}{ Respiratory, thoracic and mediastinal disorders } \\
\hline Hiccups & $3(13)$ & - \\
\hline \multicolumn{3}{|c|}{ Metabolism and nutrition disorders } \\
\hline Hyporexia & $1(4)$ & - \\
\hline Increased appetite & - & $1(4)$ \\
\hline \multicolumn{3}{|l|}{ Investigations } \\
\hline Increased liver enzymes & $2(8)$ & $1(4)$ \\
\hline \multicolumn{3}{|l|}{ Cardiac disorders } \\
\hline Palpitations & $5(21)$ & $2(8)$ \\
\hline \multicolumn{3}{|c|}{ Musculoskeletal and connective tissue disorders } \\
\hline Upper limb weakness & $1(4)$ & - \\
\hline Left shoulder pain & - & $1(4)$ \\
\hline \multicolumn{3}{|l|}{ Eye disorders } \\
\hline Photophobia & - & $1(4)$ \\
\hline
\end{tabular}

